\title{
Is Flexible Labor Good for Innovation? Evidence from Russian Firm-level Data
}

\author{
Larisa Smirnykh ${ }^{\text {a }}$ \\ Deputy Head of Laboratory and Professor, Faculty of Economic Sciences, lsmirnykh@hse.ru. \\ a National Research University Higher School of Economics, \\ 26 Shabolovka str., Bldg 4, Office 4332, 119049 Moscow, Russian Federation
}

\begin{abstract}
$\mathrm{T}$ The level of innovation activity of the Russian enterprises is inferior to the level of innovation activity of enterprises in developed countries. At the same time, Russian enterprises actively use fixedterm contracts, which help them to reduce the labour costs and adapt to changes in demand, to increase the flexibility of labor and improve the selection of employees at the workplaces. Fixed-term contracts can contribute to innovation, because they enhance the flexibility of labor relations and create savings in the use of workers. However, fixed-term contracts can reduce the likelihood of innovation because they reduce investment in human capital, leading to a reduction in labor productivity. Which trends dominate in labour relations is the subject of this study. For the study, we was used the data about

enterprises from the annual Russian Enterprises Survey in 2014. The sample is representative for Russia and includes small, medium and large enterprises with more than 30 employees in seven sectors (mining, industry, construction, transport and communications, trade, finance, business services). For the analysis, we used bivariate probit model, Heckman correction model and probit model with continuous endogenous regressor (the share of workers with fixed-term labour contracts). The results showed that fixed-term contracts have a positive effect on the innovation activity of enterprises only when they are used in a limited quantity. With an increase in the percentage of workers in enterprises with fixedterm contracts, the likelihood of innovation activity of enterprises declines.
\end{abstract}

Keywords: innovative activity of enterprises; types of innovation; fixed-term contracts; non-standard employment; human capital and innovation; investment; Russia

DOI: 10.17323/1995-459X.2016.4.60.70.
Citation: Smirnykh L. (2016) Is Flexible Labor Good for Innovation? Evidence from Russian Firm-level Data. Foresight and STI Governance, vol. 10, no 4, pp. 60-70. DOI: 10.17323/1995-459X.2016.4.60.70. 
I $\mathrm{n}$ terms of innovation activity level, Russia (at 10.1\%) significantly lags behind not just the leading developed nations (the relevant value for Germany is $66.9 \%$ ), but also most of the Central and Eastern European countries, where this indicator's value ranges between 20-60\% [Gorodnikova et al., 2015]. At the same time Russian companies use fixed-term employment contracts on a scale comparable with the global average, more or less on a par with the UK, the US, Canada, Japan, Germany, France, and Italy [Farah, Iodice, 2013]. In 2008-2013 the average share of such contracts in the aforementioned countries was 9\%. In Russia it amounted to $14 \%$ in 2008 , and in 2013 it fell to 9\%. A third of Russian companies use fixed-term employment contracts [Smirnykh, 2014], which helps them adapt to changing demand, increase probation period for job candidates, cut layoff costs, and use temporary workers as a buffer to maintain the human capital of their permanent staff [Atkinson, 1987; Kalleberg, 2001; Cappelli, Neumark, 2004; Booth et al., 2002].

The connection between the level of companies' innovation activity and their use of fixed-term employment contracts is due to reduced risks the latter provide, by increasing employment flexibility and reducing labour costs, combined with lower employment security [Bassanini, Ernst, 2002; Scarpetta, Tressel, 2004]. At the same time this employment format creates no motivation, for employers and employees alike, to invest in human capital, which reduces companies' innovation activity [Laursen, Foss, 2003; Michie, Sheehan, 2003; Kleinknecht et al., 2006; Arvanitis, 2005; Lucidi, Kleinknecht, 2009] ${ }^{1}$. There is no consensus among scholars regarding which of the above effects prevails. Some cite data that suggest fixed-term employment contracts negatively affect companies' innovation activity [Franceschi, Mariani, 2014; Bentolia, Dolado, 1994; Autor et al., 2007; Dolado et al., 2012; Cappellari et al., 2012]. Others, on the contrary, provide evidence in favour of a positive correlation between these phenomena [Malgarini et al., 2011; Bassanini, Ernst, 2002a, 2002b; Scarpetta, Tressel, 2004; Zhou et al., 2011; Jacob, 2010; Ichino, Riphahn, 2005; Zhou et al., 2010; Bartelsman et al., 2010; Nicoletti, Scarpetta, 2003].

Russian data about the connection between use of fixed-term employment contracts and the level of companies' innovation activity is very scarce, with no studies conducted in this field to date. However, it is known that the main incentive for companies' opting for such arrangement is survival, while the main limiting factors include "shortage of the companies' own funds" (75\%) and "insufficient financial support by the state" (47\%) [Kuznetsova, Roud, 2011]. Our study was focused on fixed-term employment contracts as a labour market factor affecting companies' innovation activity, and describing employer/employee relations on the micro-level. The hypothesis about such an impact was tested using data collected during an all-Russian representative survey conducted in 2014, covering small, medium, and large companies in seven industries. The bivariate probit, Heckman, and binary probit models with a continuous endogenous regressor were used in our calculations (shares of workers on fixed-term employment contracts).

Structurally, the paper includes an introduction and three sections. The first section presents a review of literature describing, in a logical sequence, theoretical and empirical justifications of fixed-term employment contracts' negative and positive impact on companies' innovation activity. The second section describes methodology of the study, data sources, construction of variables, and analysis techniques that were used. The third section presents results and their interpretation.

\section{Literature review}

Fixed-term employment contracts' impact on companies' innovation activity varies under different circumstances. Scholars' opinions about the nature of this impact also vary: some believe that the increased use of such contracts encourages companies' innovation activities, while others hold the opposite opinion [Franceschi, Mariani, 2014; Bentolia, Dolado, 1994]. The latter's arguments are based on the premise that since companies are not very much interested in investing in training their temporary employees (if at all) [Acemoglu, Pischke, 1999; Booth et al., 2002], these employees therefore remain low-skilled and frequently change jobs, such companies' specific levels of human capital and innovation activity also remain low [AlLaham et al., 2011]. Returns on investments in staff training only increase in the framework of long-term employment relations, while with fixed-term employment contracts they fall [Wood, de Menezes, 1998]. Another negative consequence of using fixed-term employment contracts is low labour productivity [Autor et al., 2007; Dolado et al., 2012; Cappellari et al., 2012], due not only to the reduced quality of human capital but also to lower employment security, ultimately leading to employees' reduced loyalty to their employer [Spender, 1996]. Temporary workers have no interest in supporting the management's initiatives, including those aimed at stepping up the company's innovation activity [Lorenz, 1999].

Researchers who insist that fixed-term employment contracts affect companies' innovation favourably, adhere to an opposite opinion. They state that innovation activities, on the contrary, are hindered by permanent employment arrangements [Malgarini et al., 2011; Hopenhayn, Rogerson, 1993; Bassanini, Ernst, 2002a]. Strict employment laws and high job security reduce labour mobility, hindering the redistribution of jobs from stagnating or declining sectors of the economy to emerging and dynamic ones [Nickell, Layard, 1999]. Complex and expensive layoff procedures and employment security guarantees do not allow companies to flexibly adjust their workforce, and cut labour costs by applying labour-saving 
innovations [Bassanini, Ernst, 2002b; Scarpetta, Tressel, 2004]. Fixed-term employment contracts provide an opportunity to do so, and gradually increase innovation activity - since they promote labour mobility and better job matching. A flexible labour market offers job seekers better chances of finding a job where they could work most productively — which would positively affect overall productivity. High labour mobility provides a better supply of new workers and new ideas for companies, ultimately leading to their increased innovation activity.

The effectiveness of production in no small measure depends on companies' ability to survive (cyclic) economic shocks and seasonal fluctuations of demand. A tightly regulated labour market (high employment security, limitations on layoffs or replacement of personnel) negatively affects companies' productivity [Hopenhayn, Rogerson, 1993] and innovation activity [Bassanini, Ernst, 2002a]. Some authors believe that low job security encourages employees to work more productively, due to the fear of losing their jobs [Jacob, 2010; Ichino, Riphahn, 2005]. Permanent employees insured against layoffs by various employment guarantees and high layoff costs to employers may tend to try to avoid hard work, and even demand pay raises and extra benefits. There is no need to elaborate upon the negative consequences of such behaviour for companies' financial situation [Malcomson, 1997; Zhou et al., 2011]. When trade unions are strong enough, workers may also have a less-then-optimal influence on the distribution of revenues - e.g. channelling some of it into remunerations. All this may have an adverse effect on innovation [Malcomson, 1997]. Investments in innovation are highly uncertain, and involve significant risks. The opportunity to hire staff on a temporary basis allows companies to cut layoff costs to practically zero [Zhou et al., 2011]. Companies' innovation activity is likely to be the higher the more confident they are of their ability to painlessly cut staff in the case that a project fails [Bartelsman et al., 2010], which again confirms the thesis about a correlation between the use of fixed-term employment contracts and companies' innovation activity [Nicoletti, Scarpetta, 2003].

The widely diverging assessments of fixed-term employment contracts' impact on companies' innovation do not allow for definitely evaluating this correlation in Russia. Though a group of innovative companies did emerge in Russia in recent years, the country still significantly lags behind developed economies in this area [Gokhberg, Kuznetsova, 2009]. Compared with the latter nations, the Russian labour market has a number of very distinctive features [Kapeliushnikov, 2009], in particular a wide variety of techniques that economic agents use to adapt. Part-time employment, administrative leave, delayed payment of wages, the growing informal sector, and increasing application of various unconventional employment formats - all of these and more are used quite widely. Among other things, unconventional employment formats include fixed-term employment contracts, which ten years ago became commonplace in Russia [Kapeliushnikov, 2009]. Since the beginning of this upward trend in the economy this employment format not only has not been put aside but instead continued to spread, covering a significant portion of the workforce. Today the scale of Russian companies' use of fixed-term employment contracts is comparable with several European countries [Smirnykh, 2014]. But does this trend reflect a positive impact on companies' innovation activity? It is our aim to find out.

\section{Methodology of the study}

Fixed-term employment contracts' effect on companies' innovation activity was studied in the framework of the survey "Interaction of internal and external labour markets" conducted in 2014 by the HSE Laboratory for Labour Market Studies. Data was collected by interviewing managers of companies included in the all-Russian representative sample designed using two criteria: companies' size and industry. 2,003 companies employing more than 30 workers were included in the sample in 2014, specialising in seven industries: mining; manufacturing; the generation and distribution of electricity, gas, and water; construction; transport and communications; wholesale and retail trade; financial services; and real estate, including leasing and related services. This survey was particularly suitable for the purposes of our study because it provided information about both relevant issues: companies' use of fixed-term employment contracts, and their innovation activities. The non-panel sample was adjusted annually, while the questionnaire remained almost $90 \%$ unchanged; it included a series of retrospective questions, the answers to which allow for a comparison of each year's situation with others.

The companies' innovation activity variable was calculated on the basis of answers to the question "Which of the innovation activities listed below did your company invest in in 2013-2014?". A commonly accepted approach in international statistical practice was applied in our calculations, according to which 'innovative' and 'innovation-active' companies are not the same. The former implement certain types of innovations, while the latter are firms that conduct innovation activities, regardless of whether the activity resulted in the implementation of an innovation or not [OECD, 2005; UIS, 2013]. We chose to use the Rosstat approach which defines organisations' innovation activity as the degree of their participation in innovation generally, or in its specific types, during a certain period of time [Rosstat, 2016]. Accordingly, in our survey a company was considered innovation-active if during 2013-2014 it invested in innovation generally, or in the creation of specific innovation types.

The level of companies' innovation activity is usually understood as the share of companies that created technological, organisational, or marketing innovations in the total number of companies in the country, industry, or region surveyed during a certain period [Rosstat, 2016]. We have used a similar definition: 
the share of companies that have invested in at least one innovation in the total number of the surveyed companies. However, the figures we obtained were bound to differ from the Rosstat ones ${ }^{2}$ because our sample included not just mining and manufacturing companies but also covered such industries as construction, finance, trade, business services, transport and communications ${ }^{3}$. Also, Rosstat calculates the level of innovation activity separately for medium and large (annually), and small companies (once every two years). We did not divide our sample this way.

We decided not to classify companies' innovation activities, because of two reasons. Firstly, if a company "participated in an innovation activity by investing in it," that does not mean an innovation was actually created; therefore dividing such activities into completed and initiated ones does not seem possible. Secondly, in their answers company mangers frequently cited two, three, or more kinds of innovation activities they have invested in, both completed and still at the development stage, which ruled out trying to assess their overall completeness.

Three kinds of indicators were calculated on the basis of answers to the question about companies' use of fixed-term employment contracts. First, companies where the share of workers on fixed-term employment contracts was greater than zero were considered companies with fixed-term employment contracts, while the actual indicator was presented in the binary variable form: $1=$ the company does use fixed-term employment contracts, $0=$ the company does not use fixed-term employment contracts. Second, the rate of such contracts' use was calculated as the share of workers on such contracts in the company's total number of employees. Third, on the basis of the second indicator an order variable was calculated, reflecting the rate of fixed-term employment contracts' application. Five levels were used, with the lowest indicating less than $1 \%$ of workers on fixed-term employment contracts $(1: \leq 1 \%)$, and the highest - more than $40 \%$ of such workers (5:>40\%).

Fixed-term employment contracts are not an organisational innovation, and we did not consider them as such. Almost $98 \%$ of the 2014 survey participants used them - which means this kind of contracts is nothing new to most companies, so according to the Oslo Manual's criteria they cannot be viewed as organisational innovations [OECD, 2005]. The latter include only certain kinds of fixed-term employment contracts used for labour leasing or outsourcing purposes. In international statistics, labour leasing and outsourcing are counted as specific kinds of fixed-term employment contracts [OECD, 2002, pp. 170-171]. However, the data we have used allows for distinguishing them from other kinds of such contracts, while workers on fixed-term employment contracts did not include those 'leased' or employed as outsourcers. Therefore including fixed-term employment contracts in any of these innovation types would not be correct.

Control variables were built on the basis of data collected via a survey of companies taking into account standard specifications applied to assess their innovation activity. Company size was determined on the basis of the average number of employees on the payroll. According to the current legislation, ${ }^{4}$ companies with up to 100 employees were classified as small; with 101-500 workers - as medium; and with more than 500 - as large. Almost $70 \%$ of the companies included in the 2014 sample were small ones, $23.17 \%$ - medium, and 7.14\% - large (Table 1). The companies in the sample belong into the following industries (sorted by their share in the total, in descending order): wholesale and retail trade $(30.10 \%)$, manufacturing $(21.32 \%)$, business services $(20.77 \%)$, construction (11.28\%), mining (5\%), financial services (5\%), transport and communications (6\%) (Table 1). Controlling interest in an overwhelming majority of the companies (94\%) was owned by Russian or foreign entrepreneurs, i.e. they belonged to the private sector; in about $5 \%$ of the surveyed firms, state participation in ownership exceeded $50 \%$, i.e., they were state-owned companies. The average age of the companies included in the 2014 sample was 14 years. Technologically, most of them $(62.64 \%)$ were on a par with the industry's average level ${ }^{5}$, almost $30 \%$ were above it, and about $8 \%$ below it. In their averaged out employment structure $44 \%$ were manual workers; gender-wise, $32 \%$ were women.

A regression analysis was conducted in several stages. At the first stage the seemingly unrelated regressions technique was applied, using a system of simultaneous bivariate probit model equations:

$y_{i 1}=\beta X_{i 1}+\varepsilon_{i 1}$
$y_{i 2}=\beta X_{i 2}+\delta Z_{i 2}+\varepsilon_{i 2}$,

\footnotetext{
${ }^{2}$ According to the All-Russian Classification of Economic Activities (OKVED), a sample of organisations to be surveyed using federal statistical observation form No. 4-innovation "Information about organisations' innovation activities" should include organisations engaged in the following economic activities: mining (Section C); manufacturing (Section D); production and distribution of electricity, gas, and water (Section E) (except electricity trading (code 40.13.2); trading in gaseous fuel delivered through distribution networks (code 40.22.2)); communication (code 64); activities involving application of computer equipment and information technologies (code 72); research and development (starting from the 2011 report) (code 73); provision of other services (code 74) [Rosstat, 2016].

3 The Rosstat sample includes only business services related to application of computer equipment, development of software, etc. In our sample the list of relevant companies was much more extensive.

${ }^{4}$ Federal law "On promoting small and medium entrepreneurship in the Russian Federation" No. 209-FZ of 24 July, 2007. Text available at: www.consultant.ru/document/cons_doc_LAW_52144/, last accessed on 08.11.2016.

${ }^{5}$ Companies technological level means availability of equipment and technologies, their age, frequency of upgrading, and need to modernise. These indicators' values ranged for various companies in the industry between 1 (significantly below others) to 5 (significantly above others)
} 
Table 1. Descriptive statistics

\begin{tabular}{|c|c|c|c|}
\hline Variable & $\begin{array}{c}\text { Number of } \\
\text { observations }\end{array}$ & $\begin{array}{l}\text { Average } \\
\text { value }\end{array}$ & $\begin{array}{r}\text { Standard } \\
\text { deviation }\end{array}$ \\
\hline Innovations $(1=$ yes) (\%) & 1995 & 41.60 & 49.30 \\
\hline \multicolumn{4}{|l|}{ Innovation types: } \\
\hline new or significantly improved products & 1995 & 9.27 & 29.01 \\
\hline new or significantly improved production technologies & 2003 & 9.54 & 29.38 \\
\hline $\mathrm{R} \& \mathrm{D}$ & 1995 & 5.56 & 22.93 \\
\hline acquisition of machinery and equipment due to introduction of new products, etc. & 2003 & 17.92 & 38.36 \\
\hline $\begin{array}{l}\text { acquisition of new technologies (patents, licenses, etc.) due to launch of new } \\
\text { products, etc. }\end{array}$ & 2003 & 7.94 & 27.04 \\
\hline staff training, retraining, and upgrading & 1995 & 19.50 & 39.63 \\
\hline construction (acquisition), repair, conversion of buildings and premises & 1995 & 1.00 & 9.96 \\
\hline \multicolumn{4}{|l|}{ Companies with the following number of innovations: } \\
\hline 1 & 1995 & 24.46 & 43.00 \\
\hline 2 & 1995 & 9.37 & 29.15 \\
\hline 3 & 1995 & 5.06 & 21.93 \\
\hline 4 & 1995 & 1.35 & 11.56 \\
\hline 5 & 1995 & 1.05 & 10.21 \\
\hline 6 & 1995 & 0.30 & 5.48 \\
\hline Average number of innovations per company which did create innovations & 830 & 1.70 & 1.05 \\
\hline Companies with fixed-term employment contracts (\%) & 1959 & 36.60 & 48.18 \\
\hline Share of employees on fixed-term employment contracts (all companies) (\%) & 1959 & 13.43 & 25.12 \\
\hline $\begin{array}{l}\text { Share of employees on fixed-term employment contracts (companies with fixed-term } \\
\text { employment contracts) (\%) }\end{array}$ & 717 & 36.70 & 29.51 \\
\hline Companies with employee leasing (outstaffing) agreements (\%) & 1964 & 2.70 & 16.21 \\
\hline Share of employees on leasing (outstaffing) agreements (all companies) (\%) & 1964 & 0.36 & 3.59 \\
\hline $\begin{array}{l}\text { Share of employees on leasing (outstaffing) agreements (companies with employee leasing } \\
\text { (outstaffing) agreements) (\%) }\end{array}$ & 53 & 13.49 & 17.46 \\
\hline Investments (Yes=1) (\%) & 1907 & 42.53 & 49.45 \\
\hline Company age (years) & 1987 & 14.25 & 15.56 \\
\hline Share of manual workers on the payroll (\%) & 1935 & 43.70 & 30.18 \\
\hline Share of women on the payroll (\%) & 1732 & 32.14 & 27.91 \\
\hline \multicolumn{4}{|l|}{ Company size: } \\
\hline$<100$ employees & 2003 & 69.70 & 45.97 \\
\hline 101-500 employees & 2003 & 23.17 & 42.20 \\
\hline$>501$ employees & 2003 & 7.14 & 25.75 \\
\hline \multicolumn{4}{|l|}{ Ownership: } \\
\hline private Russian-owned company & 1957 & 91.82 & 27.41 \\
\hline private foreign-owned company & 1957 & 2.15 & 14.50 \\
\hline state-owned company & 1957 & 4.80 & 21.39 \\
\hline mixed ownership & 1957 & 1.23 & 11.01 \\
\hline \multicolumn{4}{|l|}{ Company's technological level compared with other companies in the industry: } \\
\hline significantly below average & 1906 & 3.15 & 17.47 \\
\hline slightly below average & 1906 & 4.98 & 21.77 \\
\hline average & 1906 & 62.64 & 48.39 \\
\hline slightly above average & 1906 & 19.62 & 39.72 \\
\hline significantly above average & 1906 & 9.60 & 29.47 \\
\hline \multicolumn{4}{|l|}{ Industry: } \\
\hline mining & 2003 & 4.99 & 21.78 \\
\hline manufacturing & 2003 & 21.32 & 40.97 \\
\hline construction & 2003 & 11.28 & 31.65 \\
\hline wholesale and retail trade & 2003 & 30.10 & 45.88 \\
\hline transport and communications & 2003 & 6.44 & 24.55 \\
\hline financial services & 2003 & 5.09 & 21.99 \\
\hline business services & 2003 & 20.77 & 40.58 \\
\hline Source: calculated by the author. & & & \\
\hline
\end{tabular}


where $y_{i 1}$ is a binary variable ( $1=$ yes, $0=$ no) measuring companies' innovation activity; $y_{i 2}$ is a binary variable $\left(1=\right.$ yes, $0=$ no) measuring companies' use of fixed-term employment contracts; $X_{i 1}$ and $X_{i 2}$ are control variables (companies' size, age, ownership, industry); $Z_{i 2}$ are variables which correlate with $y_{i 2}$, but not with $y_{i 1}$ (share of women, share of manual workers) ${ }^{6} ; \beta, \delta$ are coefficients measuring impact of explanatory variables; $\varepsilon_{i 1}, \varepsilon_{i 2}$ are accidental errors; and $i=1, \ldots N$ is the number of observations (companies). At the second stage the supposition about self-selection-induced bias of assessments was checked, and a self-selection probit (heckprob) model applied, according to which the dependent variable (innovation activity) is observable if:

$y_{i}^{\text {probit }}=\left(y_{i}^{*}>0\right)$,

where $y_{i}^{*}=\beta X_{i}+u_{i 1}$ is the unobservable probability of innovation activity,

and the following selection condition is true:

$y_{i}^{\text {select }}=\left(z_{i}+\beta X_{i}+u_{i 2}>0\right)$,

$u_{i 1} \sim N(0 ; 1) ; u_{i 2} \sim N(0 ; 1) ; \operatorname{corr}\left(u_{i 1} ; u_{i 2}\right)=\rho$,

where $X_{i}$ are control variables (companies' size, age, ownership, industry); $y_{i}^{\text {select }}$ is the use of fixed-term employment contracts (investments); $z_{i}$ is the share of women, the share of manual workers (a change in financial situation during the current year, company's age); $\beta, \gamma$ are coefficients measuring the impact of explanatory variables; $u_{i 1}, u_{i 2}$ are accidental errors; and $i=1, \ldots N$ is the number of observations (companies). If $\rho=0$, companies were selected randomly so reliable data may be obtained using a simple probit model.

At the final third stage, a positive correlation was estimated between the number of employees on fixedterm employment contracts and companies' innovation activity. Since this type of contracts serves as endogenous regressor in the innovation activity equation, the equations system based on the endogenous regressor, the binary probit model (ivprobit) ${ }^{7}$ takes the following form:

$y_{i 1}^{*}=\beta y_{i 2}+\gamma X_{i 1}+u_{i}$

$y_{i 2}=\prod_{1} X_{i 1}+\prod_{2} X_{i 2}+v_{i}$

$y_{i 1}^{*}$ is unobservable, unlike $y_{i 1}$ for which the following is true:

$y_{i 1}=\left\{\begin{array}{ll}0 & y_{i 1}^{*}<0 \\ 1 & y_{i 1}^{*}>0\end{array}\right.$,

where $i=1, \ldots N$ is the number of observations (companies); $y_{i 2}$ is the endogenous regressor's vector (the share of fixed-term employment contracts); $X_{i 1}$ is $1 \times k_{1}$ vector of exogenous control variables (companies' size, age, ownership, industry); $X_{i 2}$ is $1 \times k_{2}$ vector of the instruments (share of women, share of manual workers) which correlate with $y_{i 2}$ but do not correlate with $y_{i 1}^{*} ; \beta, \gamma$ are structural parameters' vectors; $\Pi_{1}$, $\Pi_{2}$ are abridged parameter matrixes; and $u_{i}, v_{i}$ are accidental errors.

Instrumental variables were chosen to match the requirement for their correlation with the endogenous regressor, and lack of such with a dependent variable. In the data set under consideration, such variables as the share of women and the share of manual workers matched these requirements more than others (in most cases they increase the probability of companies' using fixed-term employment contracts) [Petrongolo, 2004; Portugal, Varejao, 2009; Pfeifer, 2014; Davis-Blake, Uzzi, 1993]. At the same time no correlation was found between companies' innovation activity and the shares of women and/or manual workers on their payroll, i.e. companies with a high level of innovation activity are equally likely to have high or low shares of the above employee groups.

\section{Results}

$37 \%$ of Russian companies use fixed-term employment contracts; the number of employees on such contracts is steadily growing, and in 2014 reached $13 \%$ of the total workforce (Table 1), while in the early 2000s it remained at about 5\% [Gimpelson, 2006]. The highest share of workers on fixed-term employment contracts was noted at small enterprises (40\%), compared with $33 \%$ at medium and $27 \%$ at large companies. A descriptive analysis reveals that companies that use fixed-term employment contracts show a higher level of innovation activity (51\%) than those who do not use this form of employment (36\%) (Table 2).

The averaged-out values presented above do not reflect the diverse effects of companies' specific characteristics, i.e., they provide an incomplete picture of the nature of companies' innovation activity

\footnotetext{
${ }^{6}$ These variables do not correlate with innovations, but do correlate with fixed-term employment contracts. Women and manual workers are often employed on fixed-term contracts, so the more staff companies have, the more extensively they use this kind of employment contract.

This is a recursive model where $y_{i 2}$ is inserted in the equation for $y_{i}^{*}$, but $y_{i}^{*}$ cannot be inserted in the equation for $y_{i 2}$.
} 
Table 2. Fixed-term employment contracts and companies' innovation activity (\%)

\begin{tabular}{|l|c|c|c|}
\hline \multirow{2}{*}{ Innovation-active companies } & \multicolumn{2}{|c|}{ Fixed-term employment contracts } & \multirow{2}{*}{ Total } \\
\cline { 2 - 3 } & No & Yes & \\
\hline No & 63.54 & 48.88 & 58.18 \\
\hline Yes & 36.46 & 51.12 & 41.82 \\
\hline Total & 100 & 100 & 100 \\
\hline Source: calculated by the author.
\end{tabular}

and its correlation with the use of fixed-term employment contracts. Therefore we conducted a regression analysis; the results of its first stage have shown that data obtained by applying a model for simultaneous assessment of two equations (innovation activity and fixed-term employment contracts), or bivariate probit model (biprobit), turns out to be more complete and more reliable than data generated using a standard probit model (Table 3). The Wald test results (significance of $38.72^{\star * *}$ ) confirm the hypothesis about a correlation between unobserved remainders of the two equations, and similar characteristics of companies which do apply fixed-term employment contracts, with innovation activity. Thus, the level of the latter directly depends on the type of employment contracts used, but at the same time is also affected by self-selection, i.e. influenced by two overlaying effects:

1) a cause-and-effect relationship which directly reflects fixed-term employment contracts' impact on companies' innovation activity;

2) a false impact not directly connected with companies' innovation activity.

The self-selection effect biases the estimates, which can be corrected using the Heckman model. Our calculations $(\rho>0)$ showed that the latter provides more reliable results than the simple bivariate probit model, which confirms that companies' self-selection factor affects their innovation activity (Table 4 ). The self-selection may have been due to the 'investments effect's, since companies that did make investments

\begin{tabular}{|c|c|c|c|c|}
\hline \multirow{2}{*}{$\begin{array}{ll} & \text { Variable } \\
\text { Company size }(1=<100) & \\
\end{array}$} & \multicolumn{2}{|c|}{$\begin{array}{l}\text { Innovation activity } \\
\text { (1=yes) }\end{array}$} & \multicolumn{2}{|c|}{$\begin{array}{c}\text { Fixed-term } \\
\text { employment contracts } \\
(1=\text { yes })\end{array}$} \\
\hline & Coef. & Std. Err. & Coef. & Std. Err. \\
\hline $101-500$ & 0.08 & 0.08 & 0.02 & 0.08 \\
\hline$>501$ & $0.41^{* * *}$ & 0.14 & 0.09 & 0.14 \\
\hline Company age (years) & 0.00 & 0.00 & $0.00^{*}$ & 0.00 \\
\hline \multicolumn{5}{|c|}{ Ownership (1=private Russian-owned company): } \\
\hline private foreign-owned company & $-0.44^{\star}$ & 0.25 & -0.31 & 0.26 \\
\hline state-owned company & -0.17 & 0.16 & 0.01 & 0.17 \\
\hline mixed ownership company & -0.07 & 0.31 & -0.13 & 0.32 \\
\hline \multicolumn{5}{|l|}{ Industry (1=mining): } \\
\hline manufacturing & 0.03 & 0.17 & 0.15 & 0.17 \\
\hline construction & -0.20 & 0.18 & -0.06 & 0.19 \\
\hline wholesale and retail trade & -0.22 & 0.17 & -0.22 & 0.17 \\
\hline transport and communications & $-0.46^{\star *}$ & 0.20 & -0.24 & 0.21 \\
\hline financial service & -0.04 & 0.21 & 0.10 & 0.22 \\
\hline business services & -0.09 & 0.17 & 0.05 & 0.18 \\
\hline \multicolumn{5}{|c|}{$\begin{array}{l}\text { Company's technological level compared with other } \\
\text { companies in the industry (1=significantly below average): }\end{array}$} \\
\hline slightly below average & 0.01 & 0.24 & -0.29 & 0.25 \\
\hline average & -0.04 & 0.19 & -0.22 & 0.19 \\
\hline slightly above average & -0.02 & 0.20 & -0.19 & 0.20 \\
\hline significantly above average & -0.02 & 0.22 & -0.25 & 0.22 \\
\hline Share of manual workers (\%) & & & 0.00 & 0.00 \\
\hline Share of women (\%) & & & $-0.01^{\star * *}$ & 0.00 \\
\hline Constant & -0.13 & 0.25 & & \\
\hline /athrho & $0.27^{\star * *}$ & 0.04 & & \\
\hline rho & 0.26 & 0.04 & & \\
\hline Wald test of rho $=0, \operatorname{chi} 2(1)$ & $38.72^{\star \star \star}$ & & & \\
\hline Wald chi2(34) & $123.46^{* * *}$ & & & \\
\hline Log pseudolikelihood & -1942.22 & & & \\
\hline Number of observations & 1520 & & & \\
\hline \multicolumn{5}{|c|}{ Significance: ${ }^{*}-\mathrm{p}<10 \% ;{ }^{* *}-\mathrm{p}<5 \% ;{ }^{* *}-\mathrm{p}<1 \%$. } \\
\hline
\end{tabular}

${ }^{8}$ On the basis of answers to the survey question "Were there any major investments made in 2014 (2013) in your company's development (construction, reconstruction, repair, IT, capital repair of buildings/premises, upgrading of equipment, etc.?”, a dummy variable was constructed: $1=$ there were investments, regardless of the size; $0=$ no investments were made. The source of investments did not matter: they could have been made by the company itself, or by others. 


\section{Table 4. Probit model with self-selection (heckprob)}

\begin{tabular}{|c|c|c|}
\hline Variable & Coefficients & $\begin{array}{c}\text { Robust standard } \\
\text { errors }\end{array}$ \\
\hline \multicolumn{3}{|l|}{ Innovations ( $1=$ yes $)$} \\
\hline \multicolumn{3}{|l|}{ Company size $(1=<100)$ : } \\
\hline $101-500$ & 0.12 & 0.12 \\
\hline$>501$ & $0.50^{\star \star}$ & 0.21 \\
\hline Company age (years) & 0.00 & 0.00 \\
\hline \multicolumn{3}{|c|}{ Ownership (1=private Russian-owned company): } \\
\hline private foreign-owned company & -0.46 & 0.43 \\
\hline state-owned company & -0.02 & 0.22 \\
\hline mixed ownership & $5.13^{* * *}$ & 0.35 \\
\hline \multicolumn{3}{|l|}{ Industry (1=mining): } \\
\hline manufacturing & 0.06 & 0.22 \\
\hline construction & -0.05 & 0.24 \\
\hline wholesale and retail trade & -0.06 & 0.22 \\
\hline transport and communications & -0.24 & 0.28 \\
\hline financial services & -0.02 & 0.28 \\
\hline business services & 0.01 & 0.23 \\
\hline \multicolumn{3}{|c|}{$\begin{array}{l}\text { Company's technological level compared with other companies in } \\
\text { the industry (1=significantly below average): }\end{array}$} \\
\hline slightly below average & 0.03 & 0.30 \\
\hline average & -0.08 & 0.23 \\
\hline slightly above average & 0.14 & 0.25 \\
\hline significantly above average & -0.09 & 0.27 \\
\hline Investments (1=yes) & $0.32^{\star \star \star}$ & 0.10 \\
\hline Constant & $-0.94^{* * *}$ & 0.34 \\
\hline \multicolumn{3}{|l|}{ Fixed-term employment contracts ( $1=$ yes) } \\
\hline Share of manual workers (\%) & 0.00 & 0.00 \\
\hline Share of women $(\%)$ & $-0.01^{\star * *}$ & 0.00 \\
\hline \multicolumn{3}{|l|}{ Company size $(1=<100)$ : } \\
\hline $101-500$ & 0.10 & 0.08 \\
\hline$>501$ & 0.16 & 0.14 \\
\hline Company age (years) & $0.00^{*}$ & 0.00 \\
\hline Constant & $-0.25^{\star \star \star}$ & 0.07 \\
\hline /athrho & $0.97^{\star *}$ & 0.35 \\
\hline Rho & 0.75 & 0.15 \\
\hline Number of obs & 1557 & \\
\hline Censored obs & 1047 & \\
\hline Uncensored obs & 510 & \\
\hline Wald chi2(17) & $1327.17^{\star \star \star}$ & \\
\hline Log pseudolikelihood & -1282.984 & \\
\hline Wald test $(\mathrm{rho}=0)$ chi2 $(1)$ & $7.7^{\star \star}$ & \\
\hline \multicolumn{3}{|c|}{$\begin{array}{l}\text { Significance: }{ }^{*}-\mathrm{p}<10 \% ;{ }^{* *}-\mathrm{p}<5 \% \text {; }{ }^{* *}-\mathrm{p}<1 \% \text {. } \\
\text { Source: calculated by the author. }\end{array}$} \\
\hline
\end{tabular}

demonstrated a stronger correlation between the use of fixed-term employment contracts and innovation activities (0.18) than those who avoided making investments (0.07) (Table 5).

The third stage of analysing the nature and extent of fixed-term employment contracts' effect on companies' innovation activity revealed that in Russia the latter is inversely proportional to the share of employees on such contracts (Tables 6-7). Fixed-term employment contracts positively affect companies' innovation level only if the former's application is limited to a certain scale (Figure 1). In particular, companies'

\section{Table 5. Fixed-term employment contracts and companies' innovation activity:} effect of investments

\begin{tabular}{|c|c|c|}
\hline Model & Maximum value $\mathrm{d} y / \mathrm{d} x$ & Standard error \\
\hline Heckprobit ${ }^{\mathrm{I}}$ & $0.04^{\star \star}$ & 0.02 \\
\hline Probit if invest $=1$ & $0.07^{\star}$ & 0.04 \\
\hline Probit if invest $=0$ & $0.18^{* * *}$ & 0.03 \\
\hline
\end{tabular}


Table 6. Probability of companies' innovation activity depending on the share of employees on fixed-term contracts (ivprobit)

\begin{tabular}{|c|c|c|}
\hline Variable & Coefficients & $\begin{array}{l}\text { Robust standard } \\
\text { errors }\end{array}$ \\
\hline Share of employees on fixed-term employment contracts (\%) & $-0.02^{* * *}$ & 0.00 \\
\hline \multicolumn{3}{|l|}{ Company size $(1=<100)$ : } \\
\hline $100-500$ & 0.05 & 0.13 \\
\hline$>500$ & 0.11 & 0.25 \\
\hline Company age (years) & 0.00 & 0.00 \\
\hline \multicolumn{3}{|l|}{ Ownership (1=private Russian-owned company): } \\
\hline private foreign-owned company & -0.23 & 0.44 \\
\hline state-owned company & $-0.48^{\star *}$ & 0.25 \\
\hline mixed ownership & 0.00 & 0.00 \\
\hline \multicolumn{3}{|l|}{ Industry $(1=$ mining $)$ : } \\
\hline manufacturing & -0.04 & 0.22 \\
\hline construction & 0.01 & 0.25 \\
\hline wholesale and retail trade & -0.23 & 0.22 \\
\hline transport and communications & -0.25 & 0.27 \\
\hline financial services & -0.34 & 0.30 \\
\hline business services & -0.17 & 0.23 \\
\hline \multicolumn{3}{|c|}{$\begin{array}{l}\text { Company's technological level compared with other companies in the } \\
\text { industry ( } 1=\text { significantly below average): }\end{array}$} \\
\hline slightly below average & 0.09 & 0.34 \\
\hline average & 0.03 & 0.26 \\
\hline slightly above average & 0.31 & 0.27 \\
\hline significantly above average & -0.03 & 0.32 \\
\hline constant & $1.00^{* *}$ & 0.38 \\
\hline /athrho & $0.88^{\star * \star}$ & 0.27 \\
\hline /lnsigma & $3.33^{\star * *}$ & 0.03 \\
\hline Rho & 0.71 & 0.14 \\
\hline Sigma & 28.06 & 0.84 \\
\hline Wald test chi2(1) & $10.56^{* * *}$ & \\
\hline Wald chi2(16) & $84.21^{\star * *}$ & \\
\hline Log pseudolikelihood & -2939.39 & \\
\hline Number of observations & 543 & \\
\hline \multicolumn{3}{|l|}{$\begin{array}{l}\text { Significance: }{ }^{*}-\mathrm{p}<10 \% ;{ }^{* *}-\mathrm{p}<5 \% ;{ }^{* *}-\mathrm{p}<1 \% \text {. } \\
\text { Source: calculated by the author. }\end{array}$} \\
\hline
\end{tabular}

innovation activity reaches its peak if the share of employees on such contracts does not exceed $5 \%$ of their total payroll. Increasing this share further produces the reverse effect (Figure 1).

On the whole, it could be argued that the share of fixed-term employment contracts positively correlating with the company's innovation activity will vary in different industries and groups of firms. Establishing its optimal values for particular company profiles and sizes requires further research.

\section{Conclusion}

In terms of companies' innovation activity level, Russia noticeably lags behind developed countries. Progress in this area can be encouraged not just by providing direct public support but also by establishing rules and norms (i.e. labour market regulatory mechanisms) aimed at making this market more flexible, optimising employers' costs, and extended application of fixed-term employment contracts and other

Table 7. Probability of companies' innovation activity depending on the share of employees on fixed-term contracts: maximum values (ivprobit)

\begin{tabular}{|c|c|c|}
\hline Variable & Maximum value (dy/dx) & Standard error \\
\hline $\begin{array}{l}\text { Share of employees on fixed-term employment } \\
\text { contracts }(\%)\end{array}$ & $-0.01^{* * *}$ & 0.00 \\
\hline $\begin{array}{l}\text { Levels by the number of employees on fixed-term } \\
\text { employment contracts }(1 \leq 1 \% ; 5>40 \%)\end{array}$ & $-0.15^{\star * *}$ & 0.04 \\
\hline \multicolumn{3}{|l|}{ Significance: ${ }^{*}-\mathrm{p}<10 \%{ }^{* *}-\mathrm{p}<5 \%{ }^{* * *}-\mathrm{p}<1 \%$. } \\
\hline Source: calculated by the author. & & \\
\hline
\end{tabular}




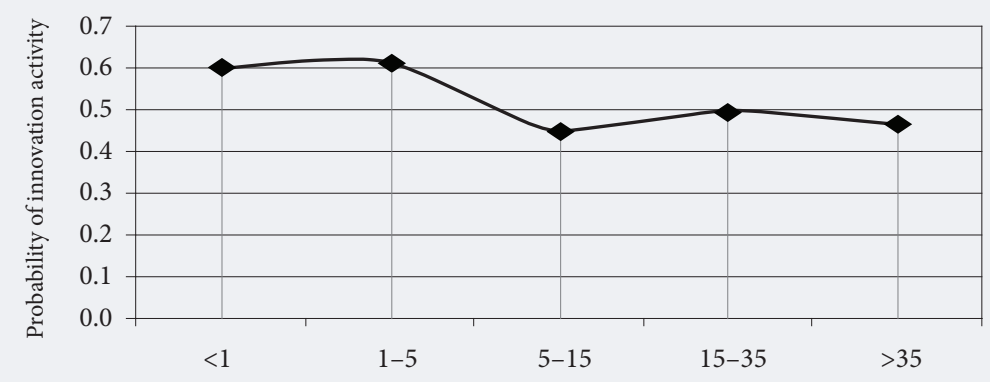

Share of fixed-term employment contracts (\%)

Source: compiled by the author.

unconventional employment arrangements. The effect of fixed-term employment contracts on Russian companies' innovation activity was comprehensively analysed in our study for the first time ever. Over the last seven years, the share of such contracts remained high, frequently exceeding the level of certain European countries. The results of further increasing the flexibility of the Russian labour market by an even more active use of this mechanism may turn out to be ambiguous.

A regression analysis of companies' characteristics revealed that those who do use fixed-term employment contracts frequently turn out to be innovation-active. However, if the share of workers on such contracts in the companies' total payroll increases, the companies' innovation activity declines. It reaches its peak level when about $5 \%$ of the company's total workforce are employed on fixed-term contracts. Increasing this share may lead to reduced quality of human capital required for innovation. Thus, companies' innovation activity requires not just flexible employment arrangements but also a certain level of workers' skills, which for permanent employees can be upgraded through workplace training.

The results of our study may help design labour market regulation initiatives to reduce barriers hindering companies' innovation activities. Liberalising labour legislation, and improving employment policy should create incentives to develop and implement innovations. At the same time it would be impossible to cover in a single study the full range of issues related with application of flexible employment arrangements and companies' innovation activity to increase their competitiveness. Subsequently we will have to find out whether the application of fixed-term employment contracts and other employment arrangements affects companies' innovation activities during periods of economic growth and recession in a different way. The hypothesis that flexible compensation mechanisms, widely applied by Russian companies as an important adaptation technique, affect their innovation activity in a way similar to that of fixed-term employment contracts, also requires verification. All these issues remain relevant, and require further research in the context of innovation policy shaping.

This work is an output of a research project implemented as part of the Basic Research Programme at the National Research University Higher School of Economics (NRU HSE).

\section{References}

Acemoglu D., Pischke J.-St. (1999) Why Do Firms Train? Theory and Evidence. The Quarterly Journal of Economics, vol. 113, no 1 , pp. 79-119.

Al-Laham A., Tzabbar D., Amburgey T.L. (2011) The dynamics of knowledge stocks and knowledge flows: Innovation consequences of recruitment and collaboration in biotech. Industrial and Corporate Change, vol. 20, no 2, pp. 555-583. Arvanitis S. (2005) Modes of labor flexibility at firm level: Are there any implications for performance and innovation? Evidence for the Swiss economy. Industrial and Corporate Change, vol. 14, no 6, pp. 993-1016.

Atkinson J. (1987) Flexibility or fragmentation? The United Kingdom labor market in the eighties. Labor and Society, vol. 12 , no 1 , pp. 87-105.

Autor D., Kerr W., Kugler A. (2007) Do Employment Protections Reduce Productivity? Evidence from U.S. States. Economic Journal, vol. 117, no 521, pp. 189-217.

Bartelsman E., Gautier P., de Wind J. (2010) Employment Protection, Technology Choice, and Worker Allocation (IZA Working Paper no 4895), Bonn: Institute for the Study of Labor (IZA).

Bassanini A., Ernst E. (2002a) Labor market regulation, industrial relations and technological regimes: A tale of comparative advantage. Industrial Relations, vol. 11, pp. 391-426.

Bassanini A., Ernst E. (2002b) Labour Market Institutions, Product Market Regulation, and Innovation (OECD Working Paper no 316), Paris: OECD.

Bentolila S., Dolado J. (1994) Spanish labour markets. Economic Policy, vol. 9, no 18, pp. 53-99. 
Booth A.L., Francesconi M., Frank J. (2002) Labor as a buffer: Do temporary workers suffer? (IZA Discussion Paper no 673), Bonn: Institute for the Study of Labor (IZA).

Cappellari L., Dell'Aringa C., Leonardi M. (2012) Temporary Employment, Job Flows and Productivity: A Tale of Two Reforms. The Economic Journal, vol. 122, no 562, pp. 188-215.

Cappelli P., Neumark D. (2004) External churning and internal flexibility: Evidence on the functional flexibility and core-periphery hypotheses. Industrial Relations, vol. 43, no 1, pp. 148-182.

Davis-Blake A., Uzzi B. (1993) Determinants of Employment Externalization: A Study of Temporary Workers and Independent Contractors // Administrative Science Quarterly, vol. 38, no 2, pp. 195-223.

Dolado J., Ortigueira S., Stucchi R. (2012) Does dual employment protection affect TFP? Evidence from Spanish manufacturing firms (CEPR Discussion Paper no 8763), London: Center for Economic and Policy Research.

Farah D.-M., Iodice A. (2013) Trud vne pravovogo polya [The work outside the legal field]. Uroven' zhizni naseleniya regionov Rossii [Quality of Life of the Russian Population], no 10, pp. 13-14 (in Russian).

Franceschi F., Mariani V. (2014) Flexible Labour and Innovation in the Italian Sector, Rome: Bank of Italy. Available at: http://www.bancaditalia.it/pubblicazioni/altri-atti-convegni/2014-innovazione-italia/Franceschi-Mariani.pdf, accessed 19.10.2016.

Gimpelson V. (2006) Vremennaya i nepostoyannaya zanyatost' [Temporary and unstable employment]. Nestandaratnaya zanyatost' $v$ rossiiskoi ekonomike [Non-typical employment in the Russian economy] (eds. V. Gimpelson, R. Kapelyushnikov), Moscow: HSE (in Russian).

Gokhberg L., Kouznetsova I. (2009) Innovatsii v rossiiskoi ekonomike. Stagnatsiya v preddverii krizisa? [Innovation in the Russian Economy: Stagnation before Crisis?]. Foresight-Russia, vol. 3, no 2, pp. 28-46 (in Russian).

Gorodnikova N., Gokhberg L., Ditkovskiy K., Kuznetsova I., Lukinova E., Martynova S., Ratay T., Rosovetskaya L., Fridlyanova S. (2015) Indikatory innovatsionnoi deyatel'nosti: 2015. Statisticheskii sbornik [Indicators of Innovation in Russian Federation: 2015. Data Book], Moscow: HSE (in Russian).

Griliches Z. (1998) R\&D and Productivity. The Econometric Evidence, Chicago: University of Chicago Press.

Hall B.H. (2011) Innovation and Productivity (NBER Working Paper no 17178), Cambridge, MA: National Bureau of Economic Research.

Hopenhayn H., Rogerson R. (1993) Job Turnover and Policy Evaluation: A General Equilibrium Analysis. The Journal of Political Economy, vol. 101, no 5, pp. 915-938.

Ichino A., Riphahan R.T. (2005) The Effect of Employment Protection on Worker Effort: A Comparison of Absenteeism During and After Probation. Journal of the European Economic Association, vol. 3, no 1, pp. 120-143.

Jacob B. (2010) The Effect of Employment Protection on Worker Effort: Evidence from Public Schooling (NBER Working Paper no 15655), Cambridge, MA: National Bureau of Economic Research.

Kalleberg A.L. (2001) Organizing flexibility: The flexible firm in a new century. British Journal of Industrial Relations, vol. 39, no 4, pp. 479-504.

Kapelyushnikov R.I. (2009) Konets rossiiskoi modeli rynka truda? [End of the Russian labor market model?], Moscow: Fond Liberal'naya missiya [Liberal Mission Foundation] (in Russian).

Kleinknecht A., Oostendorp R.M., Pradhan M.P., Naastepad C.W.M. (2006) Flexible labour, firm performance and the Dutch job creation miracle. International Review of Applied Economics, vol. 20, № 2, pp. 171-187.

Kuznetsova T., Roud V. (2011) Faktory effektivnosti i motivy innovatsionnoi deyatelnosti rossiiskikh promyshlennykh predpriyatii [Efficiency Factors and Motivations Driving Innovative Activity of Russian Industrial Enterprises]. Foresight-Russia, vol. 5, no 2, pp. 41-42 (in Russian).

Laursen K., Foss N.J. (2003) New Human Resource Management Practices, Complementarities, and the Impact on Innovative Performance. Cambridge Journal of Economics, vol. 27, no 2, pp. 243-263.

Lorenz E.H. (1999) Trust, contract and economic cooperation. Cambridge Journal of Economics, vol. 23, no 3, pp. 301-316.

Lucidi F., Kleinknecht A. (2010) Little innovation, many jobs. An econometric analysis of the Italian productivity crisis. Cambridge Journal of Economics, vol. 34, no 3, pp. 525-546.

Malcomson J.M. (1997) Contracts, hold-up, and labour markets. Journal of Economic Literature, vol. 35, no 4, pp. 1916-1957.

Malgarini M., Mancini M., Pacelli L. (2011) Temporary Hires and Innovative Investments (University of Torino Working Paper no 19), Torino: University of Torino.

Michie J., Sheehan M. (2003) Labour market deregulation, 'flexibility' and innovation. Cambridge Journal of Economics, vol. 27, no 1, pp. 123-148.

Nickell S., Layard R. (1999) Labour market institutions and economic performance. Handbook of Labour Economics (eds. O. Ashenfelter, D. Card), Amsterdam: Elsevier Science, pp. 2985-3028.

Nicoletti G., Scarpetta S. (2003) Regulation, productivity, and growth: OECD evidence (World Bank Policy Research Working Paper no 2944), Washington, D.C.: World Bank.

OECD (2002) OECD Employment Outlook, Paris: OECD.

OECD (2005) Oslo Manual - Guidelines for Collecting and Interpreting Innovation Data, Paris: OECD.

Petrongolo B. (2004) Gender Segregation in Employment Contracts (CEP Discussion Paper no 637), London: Centre for Economic Performance.

Pfeifer C. (2009) Fixed-Term Contracts and Employment Adjustment. An Empirical Test of the Core-Periphery Hypothesis with German Establishment Data. The Economic Record, no 85(268), pp. 92-107.

Portugal P., Varejao J. (2009) Why Do Firms Use Fixed-Term Contracts? (IZA Discussion Paper no 4380), Bonn: Institute for the Study of Labor (IZA).

Rosstat (2016) Nauka i innovatsii. Ofitsialnaya statistika [Science and Innovation. Official statistics]. Available at: http:// www.gks.ru/wps/wcm/connect/rosstat_main/rosstat/ru/statistics/science_and_innovations/science/\#, accessed 15.06.2016 (in Russian).

Scarpetta S., Tressel T. (2004) Boosting Productivity via Innovation and Adoption of New Technologies: Any Role for Labour Market Institutions? (World Bank Policy Research Working Paper no 3273), Washington, D.C.: World Bank.

Smirnykh L. (2014) Srochnye trudovye dogovory: vliyanie na dvizhenie rabochei sily i rabochikh mest [Fixed-term employment contracts: The impact on the movement of labor and employment]. Uroven' zhizni naseleniya regionov Rossii [Quality of Life of the Russian Population], no 4, pp. 28-36 (in Russian).

Spender J.C. (1996) Knowledge and the Firm: Overview. Strategic Management Journal, vol. 17, pp. 45-62.

UIS (2015) Summary Report of the 2013 UIS Innovation Data Collection (Information Paper no 24), Montreal: UNESCO Institute for Statistics.

Wood S., de Menezes L. (1998) High commitment management in the UK: Evidence from the Workplace Industrial Relations Survey and Employers' Manpower and Skills Practices Survey. Human Relations, vol. 51, no 4, pp. 485-517.

Zhou H., Dekker R., Kleinknecht A. (2010) The impact of labour flexibility and HRM on innovation. Innovation in Business and Enterprise: Technologies and Frameworks (eds. L. Al-Hakim, C. Jin), Hershey, PA: IGI Global, pp. 150-161.

Zhou H., Dekker R., Kleinknecht A. (2011) Flexible labor and innovation performance: Evidence from longitudinal firm-level data. Industrial and Corporate Change, vol. 20, no 3, pp. 941-968. 